\title{
DO SMOKING, HEAVY PHYSICAL ACTIVITY, AND OVERWEIGHT, INCREASE THE RISK OF MALE INFERTILITY? A NEW EVIDENCE FROM SURAKARTA, CENTRAL JAVA
}

\author{
Devita Agustina', Uki Retno Budihastuti²), Bhisma Murti1) \\ ${ }^{1)}$ Masters Program in Public Health, Sebelas Maret \\ ${ }^{2)}$ Department of Obstetrics and Gynecology, Dr. Moewardi Hospital, \\ Surakarta
}

\begin{abstract}
Background: Male infertility is a global public health issue. Infertility affects an estimated $15 \%$ of couples globally, amounting to 48.5 million couples. Males are found to be solely responsible for $20-30 \%$ of infertility cases and contribute to $50 \%$ of cases overall. This study aimed to investigate the effects of smoking, heavy physical activity, and overweight on the risk of male infertility.

Subjects and Method: This was a cross-sectional study conducted in Sekar infertility clinic, Dr. Moewardi hospital, Surakarta, from January to May 2018. A sample of 120 men was selected by fixed disease sampling. The dependent variable was male infertility. The independent variables were age, smoking, physical activity, and body mass index (BMI). The data were collected by questionnaire and analyzed by a multiple logistic regression.

Results: Male infertility was associated with older age $(b=4.96 ; 95 \% \mathrm{CI}=1.74$ to $14.17 ; \mathrm{p}=0.003)$, smoking $(\mathrm{b}=2.83 ; 95 \% \mathrm{CI}=1.17$ to $6.84 ; \mathrm{p}=0.021)$, heavy physical activity $(b=2.84 ; 95 \% \mathrm{CI}=1.14$ to $7.06 ; \mathrm{p}=0.025)$, and $\mathrm{BMI} \geq 25(\mathrm{~b}=2.88$; $95 \% \mathrm{CI}=1.06$ to $7.85 ; \mathrm{p}=0.038$ ).
\end{abstract}

Conclusion: Male infertility is associated with age, smoking, heavy physical activity, and BMI $\geq 25$.

Keywords: infertility, smoking, physical activity, body mass index, men

\section{Correspondence:}

Devita Agustina. Masters Program in Public Health, Universitas Sebelas Maret, Jl. Ir. Sutami No. 36 A, Surakarta, Indonesia. Email: inidevita@gmail.com. 